ENVIRONMENTAL DISPUTE RESOLUTION IN INDONESIA 
For my fellow travellers - Samali, Niluka and Rama

Cover illustration: Gold mine in West Kalimantan, 2005 (photograph by Fridus Steijlen) 
V E R H A N D E L I N G E N VAN HET KONINKLIJK INSTITUUT VOOR TAAL-, LAND- EN VOLKENKUNDE

259

DAVID NICHOLSON

\section{ENVIRONMENTAL DISPUTE RESOLUTION IN INDONESIA}

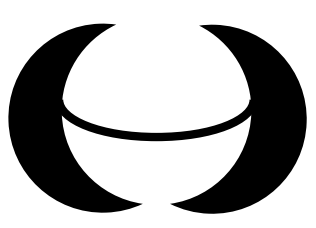

KITLV Press

Leiden

2009 
Published by:

KITLV Press

Koninklijk Instituut voor Taal-, Land- en Volkenkunde

(Royal Netherlands Institute of Southeast Asian and Caribbean Studies)

PO Box 9515

2300 RA Leiden

The Netherlands

website: www.kitlv.nl

e-mail: kitlvpress@kitlv.nl

KITLV is an institute of the Royal Netherlands Academy of Arts and Sciences (KNAW)

Research for this book was funded by the Royal Netherlands Academy of Arts and Sciences in the framework of the Scientific Programme IndonesiaNetherlands.

Cover: Creja ontwerpen, Leiderdorp

ISBN 9789067183260

(C) 2009 Koninklijk Instituut voor Taal-, Land- en Volkenkunde

No part of this publication may be reproduced or transmitted in any form or by any means, electronic or mechanical, including photocopy, recording, or any information storage and retrieval system, without permission from the copyright owner.

Printed in the Netherlands 


\section{Contents}

Acknowledgements vii

List of abbreviations $\quad$ ix

Introduction $\quad x i$

Environmental disputes in Indonesia $x i$

Academic context xii

Methodology xiii

Overview of book $\mathrm{xv}$

A note on the currency exchange rate xvii

I Environmental dispute resolution; Theoretical and Indonesian perspectives

Environmental disputes 1

Approaches to dispute resolution 4

Environmental litigation 6

Environmental mediation 21

Environmental dispute resolution in Indonesia; An overview

II Environmental litigation in Indonesia; Legal framework and overview of cases

Standing 50

Representative actions 53

Compensation for environmental damage 66

Strict liability 80

Environmental restoration 85

Right to environmental information 90

Administrative environmental litigation 93

Conclusion 111

III Case studies of environmental litigation

Banger River case, 1999118

Babon River case, 1998134 
IV Environmental mediation in Indonesia

Cultural basis for mediation 151

Legislation 153

Institutionalization of environmental mediation 156

Review of environmental mediation cases 157

Conclusion 185

V Case studies of environmental mediation

The Palur Raya dispute 191

The Kayu Lapis Indonesia dispute 215

Conclusion 238

VI Conclusion; Environmental justice in Indonesia

Environmental litigation 246

Environmental mediation 272

Comparison of environmental litigation and mediation 286

Summary of recommendations 291

Appendices

1 Overview of environmental litigation cases 296

2 Overview of environmental mediation cases 304

$\begin{array}{ll}\text { Bibliography } & 307\end{array}$

$\begin{array}{ll}\text { Index } & 325\end{array}$ 


\section{Acknowledgements}

Writing a book can often feel like a solitary task, but I was fortunate to undertake this research not alone but within the framework of the Indonesia Netherlands Study on Environmental Law (INSELA) project. I found our annual conferences in both Holland and Indonesia, and the opportunity to prepare and present an annual paper, both a support and stimulus for the direction of my own research. I would like to thank all my co-researchers on both the Dutch and Indonesian sides of the project for their collegial and academic support at various times throughout the duration of the project.

Prior to joining the INSELA project, I commenced post-graduate research at Murdoch University, where I was based at the Asia Research Centre. I am most grateful for the support of the centre during that period and also the feedback and assistance I received from a number of people at the time including Richard Robison, Kanishka Jayasuriya, Gitte Heij and Carol Warren.

Once in Holland, under the auspices of INSELA, a good part of my time was spent working on the thesis that led to this book in the attic of the Van Vollenhoven Institute, then located on the Rapenburg. I would like to acknowledge the support of the Institute and the assistance offered by all concerned (both academic and administrative staff) to myself and my family during our stay in Holland and throughout the duration of the project. Particularly thanks go to my co-researchers for their feedback, comments and companionship along the way including Julia Arnscheidt, Nicole Niessen, John McCarthy and other participants. Thanks also to Albert, Cora and Sylvia for their able research assistance at various stages and to Nel, Mariaane, Kari and most recently Jan Van Olden for administrative help along the way.

Whilst in Jakarta I was particularly grateful for the hospitable and friendly assistance offered to me by the various members of the Indonesian Centre for Environmental Law (ICEL). This assistance included access to the centre's extensive library resources, numerous discussions on various issues and assistance in the practicalities of doing research in Jakarta and beyond. Particularly I would like to acknowledge the support, comments and/or assistance I received at various stages from Mas Achmad Santosa, Wiwiek 
Awiati, Asep Warlan Yusuf, Takdir Rahmadi, Indro Sugianto, Siti Megadianty Adam, Ari Mochammed Arif, Hanif and Achmad Soleh.

Whilst researching in Solo I was generously assisted by Adi Nugroho of Gita Pertiwi, and Bapak Mutakin of Lembaga Studi Lingkungan; and I acknowledge the time and assistance provided to me by Goenawan Wibisono, Sri Hardono and various officials of Bapedal Karanganyar. In Semarang I would like to acknowledge the support of the Legal Aid Institute of Semarang, particularly the assistance I was given by Tandiono Bawor Purbaya and Poltak Ike Wibowo in researching the Kayu Lapis Indonesia dispute. In Kudus I was generously assisted by the Indonesian Foundation for Legal Service (YAPHI) whilst researching the Babon River case and in particular acknowledge Bambang, Lala and Yusuf for the assistance they gave me. Whilst in Pekalongan I was most grateful for the assistance and hospitality of Bapak Ismar during my stay there.

As may be at least partially evident from the preceding paragraphs, the research undertaken for this thesis and book involved a considerable amount of travel not only in Indonesia but also between the Netherlands and Australia. I was fortunate not to have to undertake this journey alone, but to have the constant companionship and support of my wife Samali and my children Niluka and (for part of the time at least) Rama. Samali, my heartfelt appreciation for your unwavering support throughout our extended adventure around the world and through all the packing, unpacking, relocating, cultural adjustments and all the other myriad challenges of living far from home in a foreign country. Thanks for being there and sharing the journey with me. Niluka and Rama, it certainly wouldn't have been the same without you along for the ride! Niluka, I remember your ecstatic joy at waking up to fresh snow at Christmas whilst living in Leiden. Rama, how can I forget you bouncing along in an Indonesian selendang being fed mango pieces in the tropical heat? Thanks for being your wonderful selves and making it all so much fun. 


\section{List of abbreviations}

\begin{tabular}{|c|c|}
\hline ADR & Alternative dispute resolution \\
\hline AJA & Administrative Judicature Act \\
\hline APHI & $\begin{array}{l}\text { Assosiasi Pengusaha Hutan Indonesia, Indonesian Forestry } \\
\text { Entrepreneurs' Association }\end{array}$ \\
\hline BAPPENAS & $\begin{array}{l}\text { Badan Perencanaan dan Pembangunan Nasional, the National } \\
\text { Development Planning Agency }\end{array}$ \\
\hline BATNA & Better alternative to a negotiated agreement \\
\hline BOD & Biological Oxygen Demand level (of water) \\
\hline BPPI & $\begin{array}{l}\text { Badan Penelitian dan Pengembangan Industri - Industry } \\
\text { Research and Development Institute }\end{array}$ \\
\hline CELA & Course on Environmental Law and Administration \\
\hline COD & Chemical Oxygen Demand level (of water) \\
\hline DPRD & $\begin{array}{l}\text { Dewan Perwakilan Rakyat Daerah, Regional Legislative } \\
\text { Assembly }\end{array}$ \\
\hline EIA & Environmental impact analysis \\
\hline EMA & Environmental Management Act (Indonesia) \\
\hline ICEL & Indonesian Centre for Environmental Law \\
\hline INSELA & $\begin{array}{l}\text { Indonesia-Netherlands Study on Environmental Law and } \\
\text { Administration }\end{array}$ \\
\hline IPTN & $\begin{array}{l}\text { PT Industri Pesawat Terbang Nusantara, the company to which } \\
\text { funds were transferred from the Indonesian government's State } \\
\text { Reafforestation Fund }\end{array}$ \\
\hline IPTN case & Another name for the Reafforestation Funds case \\
\hline KKL & $\begin{array}{l}\text { Konsorsium Korban Limbah, Consortium of Waste Victims, } \\
\text { an environmental advocacy group comprising members of the } \\
\text { Ngringo community and NGO workers in their dispute with } \\
\text { PT Palur Raya }\end{array}$ \\
\hline KKLB & $\begin{array}{l}\text { Kerukunan Korban Limbah Kali Banger, Association of Banger } \\
\text { River Waste Victims }\end{array}$ \\
\hline KMPL & $\begin{array}{l}\text { Kelompok Masyarakat Peduli Lingkungan, farmers' advocacy } \\
\text { group, formed from the Mangunharjo and Mangkang Wetan } \\
\text { communities against PT KLI }\end{array}$ \\
\hline KPPT & $\begin{array}{l}\text { Kelompok Pemantau Pencemaran Tyfountex, Tyfountex } \\
\text { Pollution Monitoring Group, a community group comprising } \\
\text { members of Gumpang village and neighbouring villagess }\end{array}$ \\
\hline LBHS & $\begin{array}{l}\text { Lembaga Bantuan Hukum Semarang, Semarang Legal Aid } \\
\text { Institute }\end{array}$ \\
\hline
\end{tabular}

ADR

AJA

\section{BAPPENAS}

BATNA

BOD

CELA

COD

EIA

EMA

IPTN

IPTN case

KKL

nstitute 
LKMTL

LSL

NGO

PPIPL

PT IACI

PT IIU

PT IKPP

PT IMI

PT IPU

PT KEM

PT KLI

PT PIM

PT SDC

PT SSS

WALHI

YAPHI

YLBHI

Lembaga Kesejahteraan Masyarakat Tambang dan Lingkungan, Institution for the Welfare of Mining Community and Environment, a Dayak villagers' community organization Lembaga Studi Lingkungan, a community and environmental advocacy organization

Non-government organization

Pusat Pengembangan Informasi dan Penaatan Lingkungan, Environmental Monitoring and Information Centre of the Central Environmental Impact Agency PT Indo Acidatama Chemical Industry PT Inti Indorayon Utama, a North Sumatran pulp and paper factory PT Indah Kiat Pulp and Paper company PT Indonesia Miki Industries, a group of industries comprising: PT Sumbertex (textile and plastic rope/nets producer); PT Miki Indo Industri (MSG, noodles, coffee and glucose); and PT Batang Alun (saccharin and cyclamate).

PT Indo Perkasa Usahatama company, land developers PT Kelian Equatorial Mining, a subsidiary of international mining giant Rio Tinto

PT Kayu Lapis Indonesia, a large wood-processing factory near Semarang, Central Java

PT Pupuk Iskandar Muda, owner of a liquid gas-processing factory in Northern Aceh

PT Semarang Diamond Chemical, a calcium citrate industry located on the Tapak River

PT Sarana Surya Sakti, factory in Surubaya

Wahana Lingkungan Hidup Indonesia, Indonesian National Forum for the Environment

Yayasan Pengabdian Hukum Indonesia, Indonesian Foundation for Legal Service

Yayasan Lembaga Bantuan Hukum Indonesia, Indonesian

Legal Aid Foundation 


\section{Introduction}

\section{Environmental disputes in Indonesia}

In a world of diminishing resources, exponential population growth and rapid development, environmental disputes are increasingly common phenomena. Indonesia has proven to be no exception to this global trend. Indeed environmental problems and related conflict in Indonesia have frequently assumed international dimensions. Forest fires of unprecedented scale, uncontrolled logging of old growth rainforest and the environmental fallout from some of the world's largest mines are just some of the environmental issues that have held the international spotlight in Indonesia. An even more profuse range of environmental controversies frequents the pages of the Indonesian press, including the dumping of industrial and hazardous waste, the overexploitation of natural resources, illegal logging in national parks, air pollution in overcrowded cities and flooding and landslides caused by deforestation. Within each of these complex environmental issues is a host of interrelated human disputes involving local communities, companies, local, regional and national government agencies, environmental organizations, security forces and many other parties each with their own views, interests and agenda. Such disputes, if left unresolved, can spiral into wider social conflict and exacerbate environmental degradation. In Indonesia, as in many other countries, effective mechanisms for the resolution of environmental disputes are urgently needed. This book, developed from research conducted under the auspices of the Indonesia-Netherlands Study on Environmental Law and Administration (INSELA), endeavours to address this need via a thorough documentation and analysis of the practice of environmental dispute resolution in Indonesia. The main question addressed in this book is thus: to what extent have the formal (legally prescribed) mechanisms for environmental dispute resolution (that is, litigation and mediation) actually been effective in resolving environmental disputes? 


\section{Academic context}

Research on this topic would appear to fill several significant gaps in the existing academic literature. The majority of environment related academic research to date in Indonesia has been from either an environmental studies, political science or public policy perspective. ${ }^{1}$ Whilst there has been one useful overview of environmental regulations in Indonesia (Warren and Elston 1994:74), there have been few studies from a social-legal perspective of environmental law (or dispute resolution) and its implementation. ${ }^{2}$ The INSELA project, of which this research formed a part, was intended to address this gap in the current academic literature relating to environmental law and its implementation in Indonesia. In addition, this current volume seeks to add to the growing academic fields of environmental public interest law and environmental dispute resolution. The field of environmental public interest law concerns primarily the increasingly common phenomenon of environmental public interest litigation and the legal framework within which it occurs. Whilst the early literature in this area was largely American based, over the last several decades an increasing number of comparative perspectives have become available from a range of jurisdictions. ${ }^{3}$ Nonetheless, there have not been any detailed English language studies of environmental public interest litigation or citizen-initiated enforcement of environmental law in Indonesia. Indonesian language studies of environmental law and its application are, of course, more numerous. Academic studies have provided some useful overviews of laws and associated regulations, but for the most part have not encompassed detailed examination of judicial interpretation of environmental law, nor of the surrounding social-political context and its interaction with legal processes. ${ }^{4}$ The bulk of Indonesian language commentary on environmental public interest law and its application has originated from environmental non-government organizations (NGOs) active in the area, principally the Indonesian Centre for Environmental Law (ICEL), the Indonesian Forum for the Environment (WALHI) and the Indonesian Legal Aid Foundation

$1 \quad$ See Aden 1975:987; Adicondro 1998:29-70; Aditjondro and Kowalewski 1994:381-95; Barber 1989:423; Parnwell and Bryant 1996; Cribb 1990:1123-35; Dauvergne 1994:497-518; Dauvergne 1998:13-20; Hardjono 1986:3-13; Hirsch and Warren 1998:325; Lucas 1998:229-61; Lucas and Arief Djati 2000:8; MacAndrews 1994:85-103, 369-80; Potter 1996:9-37.

2 A few exceptions in this respect include Otto 1997:21-62; Mas Achmad Santosa 1990:1-150.

3 A useful and comparative commentary on this area of law is Robinson and Dunkley 1995:342. Other references include: Cassels 1989:495; Chopra 1992:8; Cottrell 1993:102-26; Cranston 1997:233-55; Desai 1993:27-40; Denvir 1976:1133; Kramer 1996:1-18; Lau 1995:49-50; Gomez and Cottrell 1994:237; Harding 1992:231; Peiris 1991:66; Micklitz and Reich 1996:445; Susman 1994:57-103.

4 Leading Indonesian texts on environmental law include: Hamzah 1995:332; Koesnadi Hardjasoemantri 1991, 1993:358; Daud Silalahi 1992:294; Rachmadi Usman 1993:277. 
(YLBHI). ${ }^{5}$ The work of these organizations has been documented in a diverse array of case notes, practitioner reflections, press releases, newsletters, seminar papers and short articles, much of which has been invaluable in the course of the present study. ${ }^{6}$ However, more detailed and comprehensive studies, incorporating theoretical and comparative perspectives, have to date been lacking.

Literature on environmental mediation or alternative dispute resolution also had its roots in the United States, where informal modes of dispute resolution gained popularity as an alternative to litigation in the late 1970s onwards. As in the case for environmental public interest law, the literature has had a strong practitioner focus, although more recently attempts at more detailed theoretical formulations have been made. ${ }^{7}$ Whilst the practice of environmental mediation has spread outside Western countries to the developing world, there have been relatively few studies on the application of Western derived approaches to environmental mediation in countries such as Indonesia. ${ }^{8}$ Indonesian language commentaries on environmental mediation are limited, but include a useful compilation of case studies sponsored by the Ford Foundation, to which reference is made in the course of Chapter IV (Mas Achmad Santosa, Takdir Rahmadi and Adam 1997:190). To date, however, the available literature has lacked a comparative, theoretically-based study of both litigation and mediation as approaches to environmental dispute resolution, which the present study attempts to remedy.

\section{Methodology}

The research methods employed for this study have combined legal and social-scientific approaches. The theoretical discussion of environmental dispute resolution in Chapter I draws upon academic literature in the field of environmental mediation and litigation. Chapter I also includes an overview of environmental disputes in several sectors, which is based upon a compilation of written materials, including Western and Indonesian

5 These studies are referred to in subsequent chapters and generally originate from public interest environmental lawyers such as Mas Achmad Santosa (Indonesian Centre for Environmental Law).

6 Specific sources from the Indonesian Centre for Environmental Law (ICEL) and other NGOs are referred to where relevant in subsequent chapters. ICEL also publishes a useful information bulletin on environmental law and advocacy titled Hukum dan Advokasi Lingkungan and until 1999 published an environmental law journal (Jurnal Hukum Lingkungan) in Indonesian and English.

7 On this point see O'Leary 1995:17-36 and Blackburn 1990:151-70.

8 The few studies that have been done include: Moore and Mas Achmad Santosa 1995:23-9; Moore 1998:160-95; Takdir Rahmadi 1998:34-6; Mas Achmad Santosa 1996. 
academic literature, press clippings and reports by several environmental organizations. ${ }^{9}$

Chapter II provides an overview of environmental litigation in Indonesia, focusing on the legal framework and its interpretation by Indonesian courts. The primary legal sources for this chapter are the various Indonesian environmental laws and regulations discussed and the transcripts of judicial decisions from environmental cases. Copies of judicial transcripts on environmental cases were not always easy to find, due to the absence of a judicial reporting service specific to the area of environmental law. The majority of transcript copies were obtained from legal practitioners or NGOs active in the field of environmental law and advocacy. Where I refer to a judicial decision, I am referring unless otherwise noted to a copy of the judicial transcript from that decision. The discussion in Chapter II covers all civil and administrative environmental cases in Indonesia from 1982-2002 for which I have been able to obtain information. Nonetheless, the lack of reliable judicial reporting systems in Indonesia means that, whilst the chapter is illustrative, it cannot claim to be absolutely comprehensive and inclusive of all relevant environmental cases in this period. The commentary and analysis of judicial interpretation in this chapter is also based upon a range of secondary materials including press clippings, practitioner commentaries and interviews.

The four case-studies of environmental litigation and mediation discussed in Chapters III and V are based on a compilation of written materials and interviews. Written materials were of a diverse nature, including correspondence, press releases, newspaper clippings, case notes, institutional reports, photographs, and minutes of meetings gathered during the course of field visits. Interviews were conducted during several visits to Indonesia in July 1997, October 1999, May 2000 and a more extended period of field research from August 2000 until June 2001. I have also conducted several follow-up interviews in June and November 2003.10 During these periods of field research I was based in either Jakarta or Yogyakarta and often travelled to other locations throughout Java, particularly Semarang, Kudus and Pekalongan. My fieldwork and empirical research were thus Java-centred and also mainly focused on industry-related disputes, which were the most common in these areas. Interviews were generally semi-structured according to questions I had previously prepared, although usually they were conducted flexibly to allow the conversation to take its own course. Interviews were conducted with a range of actors in the selected case studies and in relation

9 Including the Indonesian Forum for the Environment (WALHI), the Indonesian Centre for Environmental Law and the London based International Campaign for Ecological Justice in Indonesia.

10 Follow-up interviews in November 2003 were conducted by phone from Perth, Australia. 
to environmental dispute resolution in general. My primary sources in this respect included local, regional and national environmental organizations involved in environmental disputes or advocacy; representatives from communities who had suffered environmental damage or pollution; legal aid practitioners involved in environmental litigation or mediation; journalists who had researched or written about high-profile environmental disputes; governmental officials from environmental agencies at the national, provincial and district level; legal academics; judges and industry representatives.

Interviews were also a source of information for several of the cases included in the overview of mediation in Chapter IV. The chapter is primarily literature-based however, as it seeks to provide an overview of reported, high profile environmental mediation cases to date in Indonesia. The overview draws upon a diverse literature including published Indonesian language studies of environmental mediation, practitioner commentaries and articles and press reports. This chapter also reflects a Java and industry-related focus, although I have included one mining dispute (the KEM dispute) located in Kalimantan. The bias of the chapter toward Java and industry-related disputes is not a comment on the lack of disputes in other areas or sectors in Indonesia. It is rather a reflection of the focus of my own empirical research, which was Java and industry related, and the focus of the available literature on environmental mediation in Indonesia, upon which I drew in compiling the overview.

\section{Overview of book}

As explained above, this research is undertaken within the broader framework of the Indonesia-Netherlands Study on Environmental Law and Administration in Indonesia (INSELA), the aim of which was to analyse environmental law and management in Indonesia from both an empirical and normative perspective and to make recommendations on the basis of that analysis. The central research question addressed by the INSELA project was as follows: What have been the consequences of the enactment and implementation of the 1997 Law on the Environment and its predecessor of 1982 for environmental management in Indonesia, and to what extent may certain legislative and policy measures, notably regarding harmonization of legislation and the decentralization of management, contribute to increased effectiveness and legal certainty in the protection of the environment?

In addressing this broad research agenda, the project was further divided into four sections: Part A focusing on national environmental and sectoral legislation and policy, Part B on decentralization and local management institutions, Part C on environmental law enforcement and dispute settle- 
ment, and Part $\mathrm{D}$ on diagnosis, comparative research, recommendations and interventions. Whilst this book addresses research questions within all of these parts, our particular focus is on Part C, relating to legal mechanisms for environmental dispute resolution. Specifically, this book examines the legal framework and legally prescribed mechanisms for environmental dispute resolution in Indonesia, namely litigation and mediation. We shall examine the extent to which such mechanisms have been effective in resolving environmental disputes, and the factors (both legal and non-legal) influencing the outcomes of litigation and mediation in environmental disputes. Finally, we shall make recommendations based on our analysis for the further development and improvement of environmental dispute resolution in Indonesia.

Chapter I begins with a discussion of theoretical perspectives on environmental disputes and environmental dispute resolution, particularly litigation and mediation, illustrated in parts with references to the Indonesian context. The discussion of litigation and mediation defines the functions, objectives and necessary conditions of these two approaches to environmental dispute resolution. This theoretical discussion provides an evaluative framework that is referred to in subsequent chapters, particularly the conclusion (Chapter $\mathrm{VI})$.

Chapter II presents a detailed study of environmental litigation in Indonesia, providing an overview of the environmental legal framework relevant to litigation and considering how key provisions have been interpreted and applied by Indonesian courts in environmental cases. The overview covers a twenty-year period, dating from 1982, when the first Environmental Management Act was enacted, to 2002. The chapter seeks to evaluate salient trends in judicial decision-making and the success of private and public interest litigants in obtaining environmental justice in this period.

In Chapter III, our examination of environmental litigation is further developed in a more detailed study of two particular cases; the Banger River dispute, and the Babon River dispute. The two case studies provide more insight into the history of the disputes, efforts to resolve the dispute before commencing litigation, and the actual process of litigation. The case study approach taken in this chapter, and later in Chapter VI, is intended to provide a more empirically grounded, politically contextualized consideration of litigation's role in resolving environmental disputes.

In Chapter IV the focus shifts to environmental mediation, with an overview of the use of mediation in Indonesia to resolve environmental disputes to date. The chapter examines the legal, institutional and cultural framework for mediation in Indonesia and includes an overview and analysis of reported mediation cases, in order to assess relevant trends in the process and outcomes of mediated environmental disputes to date. Again, the overview does not purport to be comprehensive, but rather is a selection of relatively 
high-profile environmental disputes in which a formal process of mediation was undertaken. The aim of the chapter is to identify common trends, issues, problems and outcomes in applying mediation to environmental disputes in Indonesia.

In Chapter V, a more in-depth examination of mediation is undertaken in two case studies of environmental mediation, the Palur Raya dispute and the Kayu Lapis Indonesia dispute. Each case study provides a detailed description and analysis of the mediation process, considering the different variables influencing the course of mediation with reference to the theoretical framework introduced in Chapter I. In the concluding Chapter VI, we endeavour to synthesize the insights gained from our overview and case-based analysis of environmental litigation and mediation. The chapter evaluates the outcomes of both approaches to environmental dispute resolution and considers the extent to which they have facilitated access to environmental justice in practice. The chapter then provides a concluding analysis of the legal and non-legal variables that have most noticeably influenced the process and outcomes of environmental litigation and mediation, referring to the theoretical framework elaborated in Chapter I. On the basis of this analysis, the chapter also endeavours to make recommendations to improve the effectiveness of environmental dispute resolution in Indonesia.

\section{A note on the currency exchange rate}

At the time of writing the book the exchange rate between the US dollar and the Indonesian rupiah was approximately US\$ $1: \operatorname{Rp} 7,500$. At the present time (2009) the exchange rate is approximately US\$ $1: \operatorname{Rp} 10,000$. 